\section{Experiencing post-socialism: Running and urban space in Sofia, Bulgaria}

\author{
Andrew Barnfield
}

London School of Hygiene \& Tropical Medicine, UK
European Urban and Regional Studies $1-13$

(C) The Author(s) 2016 Reprints and permissions: sagepub.co.uk/journalsPermissions.nav DOI: 10.1177/0969776416661015 eur.sagepub.com

\begin{abstract}
This article suggests that cities in Central and Eastern Europe should be understood as developing and interacting with their own unique character and challenges in their own terms. In providing an account of embodied and everyday activities, this paper challenges the conception of a decline in public-oriented acts and affordances understood via the notion of post-socialist privatism. In doing so this paper draws on ethnographic fieldwork of recreational running, an underutilised tool for urban analysis. Despite the growing interest in recreational running amongst urban scholars, engaging with the practice has remained largely neglected within research on the post-socialist cities of Central and Eastern Europe. This paper uses a case study of two recreational running clubs from Sofia, the capital of Bulgaria, offering a discussion of everyday experience, public life and urban space. This case study combines participant observation and in-depth qualitative interviews with runners and club organisers to complicate the idea of post-socialist cities as places defined by the decline of public sensibilities and a single conception of the post-socialist condition.
\end{abstract}

\title{
Keywords
}

Eastern Europe, privatism, running, Sofia, space

\section{Introduction - Everyday experiences of post- socialist cities}

Since the end of state socialism in 1989/1991 there have many attempts at thinking through the ensuing processes and trajectories affecting societies, economies and cultures that are underpinned by various geographical frameworks (Pickles, 2010; Smith and Timár, 2010). The search to comprehend a post-socialist condition has identified cities as areas that experience such developments across different spheres (Andrusz et al., 1996; Dmitrieva, 2009). However, this focus on the city tends to overlook the complex constitution of the different elements that comprise urban life. Mundane everyday practices are the way the majority of urban citizens work through different processes, including financial transactions, employment practices and forms of habitation.

The focus on everyday practices challenges the notion of grand urban theories to facilitate understanding of how citizens experience cities. In urban scholarship the turn towards urban contexts in terms of everyday actions and embodied practices has generated much insight by focusing on seemingly mundane aspects and actions of inhabiting cities (Koch and Latham, 2012). At the same time, in research on post-socialist cities, there has been a concerted effort to deviate from the idea of transition in order to think through the many experiences of post-socialism (Stenning, 2005).

Corresponding author:

Andrew Barnfield, London School of Hygiene \& Tropical Medicine, 15-17 Tavistock Place, London WC1H 9SH, UK. Email: andrew.barnfield@Ishtm.ac.uk 
Despite such research leaving behind the chimera of transition (Stenning and Hörschelmann, 2008), there has been a relative lack of attention on mundane everyday experiences in post-socialist research (Jayne and Ferenčuhová, 2014).

Reading post-socialist experience through such a focus challenges the notion that post-socialism should be perceived as a spatial distinction or regional condition. Cities and citizens have found differing ways to comprehend or contest developments; some may be distinctly related to a post-socialist identity or ways of acting while others will not. Therefore, the turn towards everyday situations highlights the many ways in which postsocialist citizens live within the contemporary world. Smith and Rochovská (2007: 1175), for example, argued that through the study of household and economic practices a better developed understanding of the processes of neoliberalism across post-socialist countries can be attained. "It is through the practices of domestication, how everyday activities are involved in the constitution of practices, subjectivities and forms of identification" (see also Stenning et al., 2010). The focus on everyday activities highlights the multitude of experiences of different post-socialist contexts and spaces.

Anthropological studies of Central and Eastern Europe (CEE) have highlighted the multitude of experiences in the years following the collapse of state socialism (e.g. for detailed accounts of everyday experiences of the demise of collectivised and social institutions across CEE, see Kideckel, 1995; Lampland, 1995; Verdery, 1996). As socialist regimes dominated formal organisational activity and means of communication, everyday anthropological accounts were critical of the attention paid to civil society for omitting more fertile practices of social life, which included opportunities that CEE citizens had to influence socialism and, in turn, post-socialism (Hann and Dunn, 1996).

Such accounts of everyday life have demonstrated that during the first years of postsocialism, rural communities struggled to maintain some of their collective institutions (Kaneff, 2004).
Creed $(1998,1999)$ has also drawn attention to the ways that socialist memories are used to propose questions of the post-socialist present, emphasising the power of ritual to inform understanding of political and economic changes in everyday activities. Meanwhile Light and Young (2014) argue, through their study of residents contesting the renaming of socialist-era squares and boulevards in Romania, that everyday habits and memory remain stable despite rupture.

This paper is an attempt to think about how to come to terms with everyday life in cities that are perceived as post-socialist by examining recreational running practices in Sofia, the capital of Bulgaria. The aims of this paper are threefold: (1) to provide an account of the everyday post-socialist urban context to add to literatures of post-socialism; (2) to explore post-socialist urbanism through embodied practice; and (3) consider the concept of "privatism" as a socio-cultural condition using recreational runners and running clubs.

The paper is divided into three parts. The first explores the landscape of post-socialist Sofia and embodied notions of being in urban space. The second introduces running, as a technique of urban inquiry, and the study methodology. The third presents the experiences of runners in Sofia, drawing attention to the efforts of running clubs to re-envision urban space and the practices of running in the city. The paper concludes by arguing that the experiences of the runners in Sofia complicate the notion of a single post-socialist condition and that it is through everyday practices that a better understood picture of life in cities can be developed.

\section{Part 1: Landscape and embodiment}

\section{Sofia, landscape and sport}

Physical activity and recreational sporting practices provide a way of accessing everyday experience in post-socialist cities that have been underutilised in urban research. Recreational running is a physical activity that is practised for fitness, exercise and wellbeing. It is not running professionally or in preparation for competitions. It involves all types of 
moving, exercising bodies engaging with different urban configurations, cultural practices and locally specific knowledges.

This paper examines running in the city of Sofia. It is a city that has been of growing interest to scholars across disciplines (Barnfield, 2016c; Kwan and Kotsev, 2015). Sofia has an intricate history of state socialism, connected to its past through the way urban space is experienced, contested and frames action (Holleran, 2014). Following a socialist coup, urban land, real estate and the means of production were nationalised in 1948 (Grigova, 2011). Housing districts, significant governmental buildings and central areas were rebuilt in the style of Stalinist socialist realism (Hirt, 2007a). The urban landscape, open squares, neighbourhoods and built form provide daily interactions with socialist vision through planning and land-use (Hirt, 2008). Added to this are the transport system and green space provision, which all give rise to particular embodied experiences of the city.

Post-socialist Sofia has experienced some aspects of urban development that have been observed in other countries of CEE (Hirt and Stanilov, 2009). For people wanting to exercise, these have been particularly evident: the rise in private car use, re-development of green space and urban retail development projects (Tsenkova and Nedovic-Budic, 2006). The under-funding of sport and health departments has also been a feature across the region, with differing results (Ganev, 2007). In socialist era Bulgaria sport was centrally organised, and the prestige of success on the world stage was highly valued. This "virtuous cycle" of sport was evident in many socialist countries (Dennis and Grix, 2012). The model prioritised funding for elite sport, hoping to increase the desire to participate in turn. In Bulgaria, specialist sport schools selected the best hopefuls and neighbourhoods frequently had sports facilities. However, recreational running was not a prominent feature in socialist Sofia. The growth in recreational running is changing this situation. Runners are seen in parks and streets, participating in events and charity runs organised by voluntary clubs.

\section{Embodiment in urban space}

Embodied notions of urban life feature in poetry, literature, film, art and social theory. Writers such as Dickens, Benjamin and Simmel have explored the bodily sensations that are experienced in a diverse array of urban spaces and lead to feelings of awe, disorientation or revulsion. Embodiment is at the heart of work by urban scholars Jacobs (1970) and Sennett (1974), who have written about interactions and encounters between bodies that characterise urban life. Sennett, in particular, has stressed the social heterogeneity that urban public space offers in the many forms of unpredictable encounters, which are both democratic and civilising.

This sentiment finds echoes in De Certeau (1984), who argues that the production of spatial meaning is reliant upon movement and bodily sensation. Meanwhile, Kenny (2014) described the role of sensation in urban space as the "feel of the city", where one learns urban space through the senses as much as the word or verbal act. Embodied sensation is suggested by Panagia (2009) as playing a pivotal role in democratic societies. Everyday activities, such as eating or the role of public notices, can help to frame a politics that is steeped in the acts of shared sensations. Panagia argues that it is through occasions such as these that new ways of democratic politics occur by redrawing what is accepted as forms of perception.

In a post-socialist context, Kalyukin et al. (2015: 18) demonstrated that notions of the public and public space have been discursively revised around specific types of sensation. Their paper suggests a second wave of post-socialism in Moscow's Gorky Park. This has entailed the development of...

...new consumption-oriented publics who embrace a European lifestyle and the implicit eviction of previously existing publics who are now deemed no longer desirable in Gorky Park. The new "public space" of Gorky Park is both safe and depoliticized whilst being carefully planned, controlled, and ordered. 
Embodied experiences exert a powerful force on mood, memory and attitude. Smell, for Śliwa and Riach (2012), is an embodied experience that branches the rupture of socialism/post-socialism, invoking memories of domestic actions of food preparation and dwelling, and everyday spaces of urban commuting on public transport. The sonic texture of urban space is discussed by Pink (2008) as a sensory sociality that works to tune bodies to each other and different objects, foregrounding techniques of place-making. For Edensor (2012: 1106), light "alters the perception of the colour and shape of space and is both a discrete material object comprising an assemblage of elements and a property that extends across space", shaping and adding layers of context to urban spaces through street lighting to illumination displays. Fear or sensations of apprehension have been explored, highlighting distinct gendered mobility patterns and the spatial tactics that actors implement when encountering or navigating fearful situations while travelling in urban space (Pain, 2001; Valentine, 1989). The literature on embodied urban experience speaks to ways people inhabit cities: how they move around, live with one another and share urban spaces.

\section{Post-socialism and the rise of the private}

In contemporary post-socialist cities, ways of living and inhabiting urban space have changed since the socialist era. This includes changing housing availability, working and shopping spaces, leisure practices and travel options. It has been argued that across European societies there has been a reduction of public sentiments and a rise of the private (Bailey, 2002). Similar arguments have been made with regard to post-socialist societies, the rise of the private acting as a hallmark of societies emerging from state-socialist control. Verdery and Humphrey (2004: 10) have called this the "enclosing of the commons". The frequent outcomes of such processes are the privatisation of formerly public resources, social segregation and exclusion. Sonia Hirt (2012) has written in Iron Curtains: Gates, Suburbs, and Privatization of Space in the Post-
Socialist City about her concept of privatism as a means of attending to the cultural context of life in Sofia. Late capitalism in a post-socialist context for Hirt (p. 17) is an era that is characterised by a culture that weakens an "appreciation of broad-based collective narratives and actions, and a growing interest in issues centred on the personal and domestic, the individual, the family".

A manifestation of privatism, for Hirt, is the construction of gated communities in Sofia. This is the spatiality and materiality of privatism, demonstrated by a desire of people wanting to leave the public realm, fostering an attitude of declining public sensibilities and affordances. However, the concept of privatism is not merely related to physical changes in the urban fabric. Hirt (2012: 3) argues with regard to Sofia that "changes in the urban environment are not only dependent on postsocialist changes in politics and economics. Rather, to the extent which space is a medium of culture, the changing urbanity of Sofia is the story of the post-socialist cultural condition". Relatedly, Bodnaŕ (2001) describes this as the dramatic reduction in the importance of the notion of public acts in all forms. Similarly, Matei (2004) describes the changes in Romanian public attitudes since 1989 to privatism, suggesting there is a hostility, due to a mass scepticism with post-Ceausescu Romania. Civic-oriented attitudes are perceived as only beneficial if there is some form of personal gain. However, privatism at best presents only a partial view of the post-socialist experience. In the context of Sofia it only speaks to certain parts of the population, living arrangements and sections of the city.

\section{Part 2: Mobilities and methods}

Post-socialist mobilities and running as method

In a recent collected edition, Burrell and Hörschelmann (2014) drew attention to mobility in socialist and post-socialist countries, identifying the potential of using the "mobilities paradigm" (Sheller and Urry, 2006). Mobility is key to understanding how people move around in everyday life, the nuts 
and bolts of everyday actions and society and how being mobile is made, represented and imagined (Adey, 2009). While the end of state socialism was envisioned as being an instigator to freedom and movement, post-socialist studies of mobilities have highlighted the contesting ways in which being mobile has materialised. For example, Bole and Gabrovec (2014) explain how the rise in automobility is a result of state subsidies for travel for employees, and the micro-geographies of carpooling are demonstrative of the notion that commuting in post-socialist countries has developed with remnants of their collectivised past. Tuvikene (2014) has highlighted the spaces of mooring, in the form of garages, and how these have become emblematic as spaces of fixity that are related to, and produced, socialist auto-mobility. Dietzsch (2014) argues that, for residents in an East German town, being mobile is bound up with the area's decline. Mobility in this sense is related to having more time through lack of employment. Residents travel by bike or foot to use more free time or to keep active in case employment in the area returns.

This paper examines recreational running and how practices of physical fitness offer an insight into post-socialist urban life. This offers a different but somewhat correlated set of embodied experiences and practices to walking (see Macpherson, 2009; Middleton, 2009, 2010 for an explication of the embodied and urban experiences of walking). Running is about movement; it involves the body becoming entangled within a field of action. It is a sensuous act, which works across a range of senses: touch, taste, sound, vision and balance. Running is an emergent process of sense-making, drawing an intimate geography of a city. This concerns the knowledge of one's body and the knowledge of the effortful cartography of urban terrain, and involves sweat and exertion, pleasure and pain. Running is a means of modulating one's experience through effort. It is convivial and a public act, the body exposed to other city dwellers and moments of collective engagement.

The potential of running to attend to the spectrum of corporeal engagement is a reason why geographers have turned towards the exercising body as a tool of urban exploration. Running holds promise for studies of post-socialist cities, by offering a means of questioning an urban landscape that has been characterised by fragmentation and change. As Latham (2015: 17) has written, recreational running has led to all sorts of experiences and habits in urban space beyond the idea of sport:

This way of configuring routine physical exercises as a palliative to an otherwise sedentary society has had all sorts of surprising consequences. One was simply the degree to which it became a normal part of the urban landscape. Another has been the proliferation in the way people use running as an exercise. Once the habit of jogging become[s] widely established it became generative of all sorts of novel practices that extended or built upon jogging's basic architecture. Think of fun runs, running clinics, big-city marathons, the contemporary fad for barefoot running, to name just a few examples.

Therefore, recreational running has given rise to a typology of what Eichberg (2002) classified as "Body Culture". This is the emergent relationship between corporeality, physical exercise and landscape. Body culture speaks to the way corporeality is enmeshed within landscape and practices of activity. Allen Collinson and Hockey (2011) wrote about running through their own experiences of training and how their bodies are shaped and re-shaped through physical exertion. They also write of the many different geographies of running, from training runs to recovering from injury and the related materialities that runners are enfolded within. While Cidell (2014: 581) described road running in charity races as a transgressive act of urban mobility that gives rise to new understandings of urban space, arguing that

Road races are therefore a prime example of how physical mobility still matters in a virtual era. Although running can and does take place almost anywhere, bringing together hundreds or thousands of runners at a time enables a 
different, transgressive occupation of space that no one runner could accomplish on his or her own.

Running is a means of experiencing urban space in a variety of ways; it fosters emergent sense-making that shapes everyday experiences (Barnfield, 2016a).

Recreational running, running clubs and study methodology

Recreational running clubs are organisations that are not-for-profit, have no mandatory membership or national affiliation, and organise weekly or monthly events, club runs and larger charity running events. The type of events included running clinics, seminars and running activism campaigning for better facilities. To research physical activity in Sofia I focused on two recreational running clubs: Begach Running Club and 5km Park-Run Sofia. The Begach club was established in 2008. The club's largest event, the Sofia Evening Run held in November 2013, attracted over 800 participants. The $5 \mathrm{~km}$ Park-Run is a regular Saturday event in Sofia and attracts over 200 participants weekly. The club has grown to other park-runs in several cities and running weekends consisting of longer events. The $5 \mathrm{~km}$ Park-Run is free of charge and runners can register or run anonymously.

The research was conducted from September 2013 to May 2014. The study participants were drawn from the two running clubs introduced above. The project consisted of participant observation of recreational running, an online quantitative survey (with 153 responses - 62 women and 91 men), and follow-up qualitative interviews with running club organisers and participants (16 interviewees - 6 female and 10 male, ages ranged from 23 to 46 years). All participants were Bulgarian. All names are anonymised.

The participants were of different levels of experience and expertise. A few had been running recreationally for over five years. However, the majority of the runners had only been doing so for three to five years. One runner had only been participating for six months. The follow-up interviews were semi-structured. They questioned, among other things, runners' use and experience of urban space, how they constructed their running routines and the technologies they used to participate. The participants were drawn from a variety of backgrounds and covered a variety of occupations. This included education, financial and legal professions. Four of the participants had lived in Sofia since childhood. Five of the participants had lived in other European countries and one participant had lived in America. The group had a mixture of socioeconomic statuses (SESS), although none of the participants was from the lowest SES group. Participant observation was used as a mean of attending to day-to-day use and experience of urban space. This included running in organised events and participating in the informal running scene in Sofia. Participant observation is a qualitative research method that aims to understand a given group or practice through involvement in their cultural setting (Burawoy, 2009; Burawoy and Verdery K 1999). I made use of the auto-ethnographic element of the research to incorporate my own experiences of running as a central source of awareness into runners' practices.

\section{Part 3: Running in Sofia}

\section{Recreational running in Sofia and privatism}

It is through examining everyday experiences and practices that this paper aims to add to studies of everyday post-socialisms by contesting the idea of a post-socialist socio-cultural condition of "privatism". The decline in public sensibilities and affordances has been suggested as characteristic of postsocialist societies (Kharkhordin, 1999). It has been defined as the significant decline in the importance of the idea of public acts in all forms and that an indifference to public activities marks everyday activities and behaviours (Bodnaŕ, 2001; Matei, 2004). In focusing on Sofia, Hirt (2012) identifies 
privatism as a cultural attitude that is evidenced through the changes to urban space, in particular through living conditions (see also Hirt and Petrović, 2011 for a Serbian perspective). This, in turn, engrains privatism through the repetition of such practices:

It is not an official ideology glorified in textbooks. But privatism transmits well: it is observed and reproduced in everyday practices. It is a popular ideology driven by multiple intentions: sometimes to withdraw from the public realm, sometimes to appropriate parts of it, and sometimes to protest against it. (p. 27)

The explanations of a decline in public life and the growth of privatism have limitations. Firstly, they rely on an implicit idealised notion of public life under state socialism, one that does not resonate with anthropological accounts (Halpern and Kideckel, 1983). Secondly, they diminish the connection between private and public to a simplistic quantitative measure. Thirdly, it is highly problematic when confronted with the emergent narratives of civic practices, such as guerrilla gardening, political protests and the developing urban cycling scene (Barnfield and Plyushteva, 2015). Fourthly, expressions of public life are restricted to housing and, in the case of Sofia, housing in a certain area. As Daskalova and Slaev (2015) reported, while the southern suburban area of Sofia (Vitohsa district) has seen a rise of intraurban relocation for gated communities or suburban housing developments by wealthy people, the northern districts (Novi Iskar and Kremikovtsi) have seen a rise of inter-urban relocation of poorer people. There have not been any developments of gated communities in this area.

However, Hirt wrote Iron Curtains before the political demonstrations in Sofia in 2013 and 2014, which brought down one government and forced the subsequent one to change ministerial appointments and policy on building on national parkland. The demonstrations provided a mixture of protestors: age, gender, background and political affiliation (Capital, 2013). This shows that there is a desire to be involved in public life and possibly the notion of privatism is itself a temporary condition. Involvement in public life is not defined by the material construction of one's place of dwelling either. As a runner explained:

I like to be running. It gives good feelings to be out in the city or on the trials. The views are changing and people are around, it is being part of Sofia. It gives me many positive emotions. I rarely do any gym work especially not running inside, I'd rather be outside. I run for recreation, for fun. I would run more in my neighbourhood if there was a specific group there, to join with and go with. That's getting better though. (Milena, F, 38)

The key point here is that a better developed understanding of the processes of post-socialism is required; recreational running is demonstrative of a desire people have of being with others in public space. So too are practices of everyday life, such as having a coffee with friends or providing transport for children.

Further, recreational running clubs present an alternative to privatism through their organisational ethos. The clubs studied in Sofia are founded on principles of openness and informality. However, the key point in relation to contesting privatism is that running clubs are a means of drawing people together and redrawing the social-geographies of urban space. The Park-Run, held weekly in South Park, is an example of people wanting to participate in a public act. As a club organiser explained:

We have all ages [running], experiences, and all that. People want to be able to something with their family for example. And we need to show them that staying fit is easy, we make it so everyone feels part, together in a big group. And plenty of encouragement. This is easy and we have to show people in Sofia that it can be part of their busy lives, people are busy but the ParkRun is only thirty minutes, an hour, OK. This isn't so difficult. (Lyubo, M, 42) 
Positioned in contrast to the narrative of the post-socialist disposition of "privatism", the interviews and participant observation of recreational runners revealed, through the development of running routines, club activities and exercise practices, a closer engagement with public life. The withdrawal from public-oriented affordances is not representative of the full spectrum of post-socialist experience in Sofia. The range of abilities required to navigate the urban landscape is demonstrative of recreational running in Sofia being part of different public lives in numerous ways. The increasing participation in recreational running is suggestive of, and gives rise to, new ways of co-habiting in post-socialist urban space (Barnfield and Plyushteva, 2015). Looking further than post-socialist cities, approaches to recreational running have shown sensory qualities, which involves being alert, and engaged with, urban life (Cidell, 2014; Latham, 2015). As my research diary notes:

Running early after the weekend's events, there all sorts of other bodies about. There is a lack of crowds this time though, but working through the streets and out across the eagle bridge towards to [national] stadium people are running. Crossing roads, waiting for traffic, dodging pedestrians, and nodding an occasional greeting. Along with cyclists, skateboarders, walkers, people doing group exercises [tai chi] and groups of teenagers, there is a lively sense to the streets. There are all shapes of public bodies, I'm sweating, breathing heavily and running, negotiating the footpaths and obstacles. The cafes spill out onto the parks tracks and people are sitting around sharing drinks, food, and music. Being together in public is a sense of everydayness, the ordinary way of life that running is a part. (Research Diary, 17 October 2013)

\section{Developing running in Sofia}

The running clubs are working to change the running environment. In organising running seminars and charity events and raising money for running infrastructure, the clubs are attempting to raise the awareness of running; as one club organiser explained "We are trying to establish running as a fitness and social activity. We want to show the people of Bulgaria that it is fun, it is easy, and that everyone can do it. We want to make running a public happening" (Stoycho, M, 33). This speaks to the ways in which the clubs are working to make room in the urban fabric for the fleshy corporeality of running bodies. Recreational running clubs organise running events, seminars and informational services. They also provide the setting for organising and envisioning urban space in particular ways. For example, through the charity events and runs that partition parks or streets as festivals of moving bodies and conviviality, and by providing space for runners to learn ideas and join recreational runs that put bodies on the streets, in neighbourhoods and in green spaces.

To go running may not need much equipment but to initiate it requires some basic information or advice. In a country where levels of inactivity and obesity are high there is the added challenge of limited public health advice or funded programmes (Dimova et al., 2012). The runners interviewed spoke of the challenges in setting out to get fit. The tactics of developing a running routine are skills that are developed by many runners for themselves. The running clubs are stepping in to help people who want to exercise. This includes people who either feel they need to exercise or may have received medical advice to improve their lifestyle. As one interviewee pointed out, it can be daunting:

I did everything wrong the first time I ran. There is no information in Bulgaria when I started. There are no national guidelines, during communist times there were, I wouldn't call them guidelines, more norms. What you should eat. But nothing now, I was very much on my own. (Milena, F, 38)

For another, the running clubs help to demonstrate how such a practice is organised and developed: 
I started to run due to weight gain after starting a different job. I have a family now and needed to be healthy for them. There is no information here at all, maybe there was years ago but not now. I read some books and used the internet to see things like nutrition and distance, I went from there and I used to run around the football stadium [CSKA] in the central park but they do not have it open anymore. The club provides information, some basic and some advanced. (Danil, M, 30)

\section{Running and experiences of urban Sofia}

Landscapes are saturated with past associations (Rose, 2006). This is either in the built form or the imaginative resonances of previous buildings, names or uses (Light and Young, 2013). In Sofia this means there are big open plazas, neighbourhoods of high-rise apartment blocks and a compact central area ( $\underline{\text { Hirt, 2007b) }}$. The socialist landscape of Sofia is part of the experiences of a post-socialist city. As my running diary testifies:

From the apartment block, a five story 1950's socialist building, across the park, another landmark to socialism, this one a memorial to a Bulgarian general, and on towards the parliament and Nevksi cathedral, the boulevard is wide and open to many lanes of traffic and transport. Through the narrow lanes of Avenue Shishman with lots of pedestrians and shoppers, keeping straight on past the Temple Shevti and the book markets skipping over the tram lanes and through the aromatic smells of banitsa and Mekitsi. Out again onto another wide boulevard that was busy with lots of fast traffic, here there is an incline as I can see the Palace of Culture (NDK) rising in the background. Into NDK Park, all concrete, some crumbling and uneven, trees line the central area with the last, and unfinished, Soviet monument standing somewhat shakily. Again people are out, many people eating or drinking, smells of food and sounds of music and films fill the air. The park is a concrete desert. (Research Diary, 3 April, 2014)
Running is not for everyone, but it does speak to ways of inhabiting post-socialist Sofia in different forms of experience. Recreational running, while not at the levels of cycling and not as influential in terms of activism and political representation, is becoming more popular (Barnfield, 2016b). Runners are not seen as weird or out of place for exercising in the streets or parks. That being said, for the runners I interviewed and surveyed, the primary space for running was in the park. However, this was also changing, with one interviewee explained that "I can run to work as my company has built showers. They also have a company transport bus so I could run home, it is far and it is easy to take this both ways" (Yvegny, $M$, 38). Finding somewhere suitable to run is a challenge in most cities and urban spaces. In Sofia, comments about the possible facilities were typical from the runners who were interviewed, for example, one runner explained "There are stray dogs which are a problem if you are nervous around them and can be dangerous. The roads are crowded and the air is not so good in the streets. Cars park all over the sidewalk" (Yanna, F, 36).

Infrastructure, public transportation, a range of construction - both large-scale works (on the second and third line of the metro) and suburbanisation present particular challenges about being in public, particularly participating in a physical activity such as running. As one runner explained, the quality of the urban fabric can be perceived as constraint on anyone wanting to exercise, "The road facilities are really bad. The landscape of the city restricts runners; the quality of the sidewalk is poor. Runners need proper trails" (Yelena, F, 38). Another runner explained that they perceived the built environment as a precarious exercise space, "Safety is a big issue for me, the streets and roads are too dangerous. The parks are better but not enough running tracks" (Yourdan, M, 40). Added to this are the levels of vehicular traffic, quality of lighting and standards of maintenance that play a part in creating experiences of urban space in relation to exercise routines; as an experienced runner noted, "there is the air pollution, no sidewalks, and where there is some pavements they are very badly maintained" (Maria, F, 34). There has been a significant rise in car ownership in Sofia 
that has coincided with the underfunding of urban infrastructure (Grozdanov, 2011). This affects not only exercise but also active transport practices, shaping the ways people move about the city. These issues have been experienced in other post-socialist cities, and are aspects that connect cities to varying degrees in the way they are confronted and challenged by citizens: decaying urban infrastructure, underfunded resources and mass suburbanisation (Stanilov and Sýkora, 2014).

Yet, people are running. There are many tactics and skills that need to be developed to negotiate space and run in Sofia. This involves competing with pedestrians and cyclists for space on the footpaths and waiting at junctions for public and private transport. For one runner this was really difficult, as she had spent time in Vienna and regularly ran to work and for leisure but it was more competitive in Sofia:

It gets crowded and people do not make room for each other. You have to be bold and go for it, no one will let you come onto the path. Some places are not designed even for people! It is all for the cars to go fast. It is disappointing. (Elena, F, 31)

Some of the challenges faced by runners, the dayto-day tactics of finding space to run and negotiating with pedestrians and traffic, are experienced by runners in cities across Europe. However, the development of running as a growing practice for fitness is assembled in way that has certain specifies to Sofia. The lack of awareness of runners, limited guidance for runners and features of the urban fabric highlight the local issues that runners in Sofia experience.

There is a plurality of similar experiences in many cities across Europe. Nikolov, a new runner, explained his route:

I like to run in my area [neighbourhood]. I have a small journey [route] that I can do and am able to make several laps and I know the distance that way too. There are some people walking but not many runners. I started getting some funny looks but not anymore. (Nikolov, M, 28)
The runners spoke of the many different experiences they had when first starting out. Some found it difficult to begin to fit running into their exercise routines as it predominately entailed running in the park, which they had to get to. As they became more experienced or if were new to running through the running clubs, they ran in their neighbourhoods or local routes. More research would be required to work through how these new spaces and patterns of physical activity are opening up or enhancing different forms of exclusion. The runners in the clubs that were part of this research were representative of Sofia, covering a mixture of backgrounds and occupations. They would not be representative of the rest of the country and, with the running clubs starting to hold events throughout Bulgaria, this promises to be an interesting opportunity for further research. Recreational runners in Sofia highlight the limitations of understanding post-socialist cities through a single, unifying concept.

\section{Conclusion}

The aim of this paper has been to emphasise the importance of everyday actions and embodied practices in research on post-socialist cities. In providing an account of everyday post-socialist urban contexts, recreational running shows that post-socialist urbanism is not easily defined by a spatial characteristic or cultural condition. Rather, the experiences of the runners in Sofia highlight that some elements or practices are inflected with certain post-socialist elements, while others are not. The locally specific nature to understanding and experiencing post-socialist urbanism means that more effort is required to get to the grips with these cities. Instead of comparing cities from CEE to Western cities, it would be more productive to see them in their own terms. While cities in the region may share similar experiences and histories, mobility practices draw attention to the many contestations that occur between them, precluding a regional spatial condition (Burrell and Hörschelmann, 2014). Further, the focus on smallscale practices and routines questions the drive for 
greater theorisation of what can be classified as urban. The conditions of being, living or participating in the urban are best described by examining the small things of which daily life is comprised. In this way, connections about responses and effects of urban living can be made through the practices and affects of urban dwellers across diverse cities throughout the world.

Running involves immersing oneself into public space; it is a public act that develops one's understanding of urban space through exertion, planning and repetition. Analysis of post-socialist cities would benefit from incorporating a differentiated approach to understanding contemporary urban life. As anthropological and geographical accounts of the region are testament, people's lives are shaped through living with, contesting and reframing urban processes (Creed, 1998; Light and Young, 2014). This is done through being in urban space, rubbing up alongside other bodies and objects and participating in all sorts of different actions that give rise to different emotions and experiences. Embodied studies of post-socialist cities have the potential to disrupt perceived ideas about what post-socialism is, how it is experienced and, in some cases, the relationship between socialism and post-socialism (Śliwa and Riach, 2012). This has the potential to open new avenues to examine how post-socialism is affected by postEuropean Union (EU) ascension migration and, in turn, how post-socialism is affecting contemporary life in the rest Europe. This would see the concept of post-socialism evolve, like other post-concepts, to embrace greater explanatory muscle in contemporary social thought (Stenning, 2005).

Recreational running clubs complicate the picture of privatism that has been described as the contemporary condition of Sofia (Hirt, 2012). The focus of one running club studied was on raising money through events to pay for improvements in running infrastructure in urban spaces: the aim is to increase the numbers of runners of all ages. Recreational running clubs are testament to the diversity and expression that fill public life and urban space in Sofia. The clubs help to provide a way of people engaging in public acts, with participants exercising unprotected as they move in urban space. The runners, in their interviews, explained that they faced with challenges and had many positive experiences. The focus on privatism in post-socialist cities does not allow room for the plurality of experiences of post-socialist urban space.

In praising running and public sensibilities in Sofia, this paper is not valorising the shortcomings of infrastructure provision as a means to developing public-oriented attitudes. It also is not suggesting that these conditions are unique to Sofia or Bulgaria. Instead, the interviews and ethnographicinfluenced work highlights that, in contemporary post-socialist urban space, there are many practices that are over-looked. These include daily interactions that are about being together in public and the new forms of collective life that are shaping post-socialist cities in the pluralistic ways that recreation running clubs foreground. Despite the limited information for public health activities such as running, the citizens of Sofia still want to go out in the city and run with other runners or just other bodies going about their daily activities. Postsocialist cities are experienced, understood and contested through such everyday acts.

\section{Acknowledgements}

I would like to thank the runners and organisers of the Begach Running Club and 5km Park-Run Sofia. They were all generous with their time and enthusiasm for the project. In addition I would like to thank Atanas Batakliev for his historical knowledge of Bulgaria and his detailed understanding of the complex developments to and from a socialist state, Boris Ishev for his practical knowledge of the physical activity landscape during and after socialist Bulgaria, and Anna Plyuhsteva for providing cogent comments on an early draft. Finally, I would also like to thank both anonymous reviewers and the editor Adrian Smith for their incredibly helpful and knowledgeable comments and suggestions for this paper, which has been much improved as a result.

\section{References}


Adey P (2009) Mobility. Oxford: Routledge.

Allen-Collinson J and Hockey J (2011) Feeling the way: notes toward a haptic phenomenology of scuba diving and distance running. International Review for the Sociology of Sport 46(3): 330-345.

Andrusz G, Harloe M and Szelényi I (1996) Cities after Socialism. Oxford: Blackwell.

Bailey J (2002) From public to private: the development of the concept of the "private". Social Research 69(1): 15-31.

Barnfield A (2016a) Affect and public health choreographing atmospheres of movement and participation. Emotion, Space and Society 20: 19.

Barnfield A (2016b) Physical exercise, health, and postsocialist landscapes: recreational running in Sofia, Bulgaria. Landscape Research. DOI: 10.1080/01426397.2016.1197193.

Barnfield A (2016c) Public health, physical exercise and non-representational theory - a mixed method study of recreational running in Sofia, Bulgaria. Critical Public Health 26(3): 281-293.

Barnfield A and Plyushteva A (2015) Cycling in the postsocialist city: on bicycle commuting in Sofia, Bulgaria. Urban Studies. DOI: 10.1177/0042098015586536.

Bodnaŕ J (2001) Fin de Millénaire Budapest: Metamorphoses of Urban Life. Minneapolis, MN: University of Minnesota Press.

Bole D and Gabrovec M (2014) Geography of daily mobilities in post-socialist European countries: evidence from Slovenia. In: Burrell $\mathrm{K}$ and Hörschelmann K (eds) Mobilities in Socialist and Post-socialist States: Societies on the Move. London: Palgrave Macmillan, pp. 217-234.

Burawoy M (2009) The extended case method. Sociological Theory 16(1): 4-33.

Burawoy M and Verdery K (1999) Uncertain Transition: Ethnographies of Change in the Postsocialist World. New York: Rowman \& Littlefield.

Burrell K and Hörschelmann K (2014) Mobilities in Socialist and Post-socialist States: Societies on the Move. London: Palgrave Macmillan.

Capital Weekly (2013) The citizen with the bike. Capital Weekly. Available at: http://www.capi tal.bg/politika_i_ikonomika/bulgaria/2013/09/ 29/2149821_grajdaninut_s_k oleloto/ (accessed 1 February 2014) [in Bulgarian]

Cidell J (2014) Running road races as transgressive event mobilities. Social \& Cultural Geography. DOI: 10.1080/14649365.2014.908236.

Creed G (1998) Domesticating Revolution: From Socialist Reform to Ambivalent Transition in a Bulgarian Village. University Park, PA: Penn State University Press.

Creed G (1999) Deconstructing socialism in Bulgaria. In: Burawoy $\mathrm{M}$ and Verdery $\mathrm{K}$ (eds) Uncertain Transition: Ethnographies of Change in the Postsocialist World. New York: Rowman \& Littlefield, pp. 223-243.

Daskalova D and Slaev AD (2015) Diversity in the suburbs: socio-spatial segregation and mix in postsocialist Sofia. Habitat International 50: 42-50.

De Certeau M (1984) The Practice of Everyday Life. Berkeley, CA: University of California Press.

Dennis M and Grix J (2012) Sport under Communism: Behind the East German Miracle. Basingstoke: Palgrave Macmillan.

Dietzsch I (2014) Life-worlds of deceleration: reflections on the 'new mobilities paradigm' through ethnographic research in post-socialist Germany. In: Burrell K and Hörschelmann K (eds) Mobilities in Socialist and Post-socialist States: Societies on the Move. London: Palgrave Macmillan, pp. 240-259.

Dimova A, Rohova M, Moutafova E, Atanasova E, Koeva S, Panteli D, van Ginneken E. (2012) Bulgaria: Health system review. Health Systems in Transition, 14(3):1-186

Dmitrieva M (2009) The Post-socialist City: Continuity and Change in Urban Space and Imagery. Berlin: Jovis Verlag.

Edensor T (2012) Illuminated atmospheres: anticipating and reproducing the flow of affective experience in Blackpool. Environment and Planning D 30(6): 1103-1122. 
Eichberg H (2002) Body Cultures: Essays on Sport, Space \& Identity by Henning Eichberg. London: Routledge.

Ganev VI (2007) Preying on the State: The Transformation of Bulgaria after 1989. Ithaca, NY: Cornell University Press.

Grigova V (2011) The city and the nation: Sofia's trajectory from glory to rubble in WWII. Journal of Urban History 37(2): 155-175.

Grozdanov V (2011) Urban mobility problems in Sofia. Paper presented at 20th international scientific conference on transport, Sofia, 4-5 November. Sofia: Transport Conference Proceedings.

Halpern JM and Kideckel DA (1983) Anthropology of Eastern Europe. Annual Review of Anthropology 12: $377-402$.

Hann CM and Dunn E (1996) Civil Society: Challenging Western Models. London: Routledge.

Hirt S (2007a) Post-socialist urban forms: notes from Sofia. Urban Geography 27(5): 464-488.

Hirt S (2007b) The compact versus the dispersed city: history of planning ideas on Sofia's urban form. Journal of Planning History 6(2): 138-165.

Hirt S (2008) Landscapes of postmodernity: changes in the built fabric of Belgrade and Sofia since the end of socialism. Urban Geography 29(8): 785810.

Hirt S (2012) Iron Curtains: Gates, Suburbs and Privatization of Space in the Post-socialist City. London: John Wiley \& Sons.

Hirt S and Petrović M (2011) The Belgrade wall: the proliferation of gated housing in the Serbian capital after socialism. International Journal of Urban and Regional Research 35(4): 753-777.

Hirt S and Stanilov K (2009) Twenty Years of Transition: the Evolution of Urban Planning in Eastern Europe and the Former Soviet Union 1989-2009 (Human Settlements Global Dialogue Series). Nairobi, Kenya: UN HABITAT.

Holleran M (2014) 'Mafia baroque': post-socialist architecture and urban planning in Bulgaria. British Journal of Sociology 65(1): 21-42.

Jacobs J (1970) The Economy of Cities. London: Penguin.
Jayne M and Ferenčuhová S (2014) Comfort, identity and fashion in the post-socialist city: materialities, assemblages and context. Journal of Consumer Culture. DOI: 10.1177/1469540513498613.

Kalyukin A, Borén T and Byerley A (2015) The second generation of post-socialist change: Gorky Park and public space in Moscow. Urban Geography. DOI: 10.1080/02723638.2015.1020658.

Kaneff D (2004) Who Owns the Past? The Politics of Time in a 'Model' Bulgarian Village. New York: Berghahn Books.

Kenny N (2014) The Feel of the City: Experiences of Urban Transformation. Toronto, ON, Canada: University of Toronto Press.

Kharkhordin O (1999) The Collective and the Individual in Russia: A Study of Practices. Berkeley, CA: University of California Press.

Kideckel D (1995) East European Communities: The Struggles for Balance in Turbulent Times. Boulder, CO: Westview Press.

Koch R and Latham A (2012) Rethinking urban public space: accounts from a junction in West London. Transactions of the Institute of British Geographers 37(4): 515-529.

Kwan MP and Kotsev A (2015) Gender differences in commute time and accessibility in Sofia, Bulgaria: a study using 3D geovisualisation. The Geographical Journal 181(1): 83-96.

Lampland M (1995) The Object of Labor: Commodification in Socialist Hungary. Chicago, IL: University of Chicago Press.

Latham A (2015) The history of a habit: jogging as a palliative to sedentariness in 1960s America. Cultural Geographies 22(1): 103-126.

Light D and Young C (2013) Urban space, political identity and the unwanted legacies of state socialism: Bucharest's problematic Centru Civic in the post-socialist era. Nationalities Papers 41(4): 515-535.

Light D and Young C (2014) Habit, memory, and the persistence of socialist-era street names in postsocialist Bucharest, Romania. Annals of the Association of American Geographers 104(3): 668685. 
Macpherson H (2009) The inter-corporeal emergence of landscape: negotiating sight, blindness and ideas of landscape in the British countryside. Environment and Planning A 41(5): 1042-1054.

Matei S (2004) The emergent Romanian postcommunist ethos from nationalism to privatism. Problems of Post-Communism 51(2): 40-47.

Middleton J (2009) 'Stepping in time': walking, time, and space in the city. Environment and Planning A 41(8): 1943-1961.

Middleton J (2010) Sense and the city: exploring the embodied geographies of urban walking. Social \& Cultural Geography 11(6): 575-596.

Pain R (2001) Gender, race, age and fear in the city. Urban Studies 38(5-6): 899-913.

Panagia D (2009) The Political Life of Sensation. Durham, NC: Duke University Press.

Pickles J (2010) The spirit of post-socialism: common spaces and the production of diversity. European Urban and Regional Studies 17(2): 127-140.

Pink S (2008) An urban tour: the sensory sociality of ethnographic place-making. Ethnography 9(2): 175-196.

Rose M (2006) Gathering 'dreams of presence': a project for the cultural landscape. Environment and Planning D 24(4): 537-554.

Sennett R (1974) The Fall of Public Man. New York: Alfred A. Knopf.

Sheller M and Urry J (2006) Mobile Technologies of the City. Oxford: Routledge.

Śliwa M and Riach K (2012) Making scents of transition smellscapes and the everyday in 'old' and 'new' urban Poland. Urban Studies 49(1): 23-41.

Smith A and Rochovská A (2007) Domesticating neoliberalism: everyday lives and the geographies of post-socialist transformations. Geoforum 38(6): 1163-1178.

Smith A and Timár J (2010) Uneven transformations: rethinking the spaces of economy and society twenty years after the collapse of state socialism. European Urban and Regional Studies 17(2): 115125.
Stanilov K and Sýkora L (eds) (2014) Confronting Suburbanization: Urban Decentralization in Postsocialist Central and Eastern Europe. London: John Wiley \& Sons.

Stenning A (2005) Post-socialism and the changing geographies of the everyday in Poland. Transactions of the Institute of British Geographers 30(1): 113-127.

Stenning A and Hörschelmann K (2008) History, geography and difference in the post-socialist world: or, do we still need post-socialism? Antipode 40(2): 312-335.

Stenning A, Smith A, Rochovská A and Świątek D (2010) Domesticating Neo-liberalism: Spaces of Economic Practice and Social Reproduction in Post-socialist Cities. London: John Wiley \& Sons.

Tsenkova S and Nedovic-Budic Z (eds) (2006) The Urban Mosaic of Post-socialist Europe: Space, Institutions and Policy. London: Springer.

Tuvikene T (2014) Mooring in socialist automobility: garage areas. In: Burrell $\mathrm{K}$ and Hörschelmann $\mathrm{K}$ (eds) Mobilities in Socialist and Post-socialist States: Societies on the Move. London: Palgrave Macmillan, pp. 105-121.

Valentine $G$ (1989) The geography of women's fear. Area 24(1): 385-390.

Verdery K (1996) What Was Socialism, and What Comes Next? Princeton, NJ: Princeton University Press.

Verdery K and Humphrey C (2004) Property in Question: Value Transformation in the Global Economy. Oxford: Berg Publishers. 